\title{
Simultaneous manipulation of multiple genes within a same regulatory stage for iterative evolution of Trichoderma reesei
}

\author{
Xianhua Sun ${ }^{1}$, Yazhe Liang ${ }^{1}$, Yuan Wang ${ }^{1}$, Honglian Zhang ${ }^{1}$, Tong Zhao ${ }^{2}$, Bin Yao ${ }^{1}$, Huiying Luo', \\ Huoqing Huang ${ }^{1 *}$ and Xiaoyun Su ${ }^{1 *}$ (D)
}

\begin{abstract}
Background: While there is growing interest in developing non-canonical filamentous fungi as hosts for producing secretory proteins, genetic engineering of filamentous fungi for improved expression often relies heavily on the understanding of regulatory mechanisms.

Results: In this study, using the cellulase-producing filamentous fungus Trichoderma reesei as a model system, we designed a semi-rational strategy by arbitrarily dividing the regulation of cellulase production into three main stagestranscription, secretion, and cell metabolism. Selected regulatory or functional genes that had been experimentally verified or predicted to enhance cellulase production were overexpressed using strong inducible or constitutive promoters, while those that would inhibit cellulase production were repressed via RNAi-mediated gene silencing. A T. reesei strain expressing the surface-displayed DsRed fluorescent protein was used as the recipient strain. After three consecutive rounds of engineering, the cellulase activity increased to up to 4.35-fold and the protein concentration increased to up to 2.97 -fold in the genetically modified strain.

Conclusions: We demonstrated that, as a proof-of-concept, selected regulatory or functional genes within an arbitrarily defined stage could be pooled to stimulate secretory cellulase production, and moreover, this method could be iteratively used for further improvement. This method is semi-rational and can essentially be used in filamentous fungi with little regulatory information.
\end{abstract}

Keywords: Trichoderma reesei, Semi-rational, Cellulase, High-throughput, Automation, Biofuel

\section{Background}

The filamentous fungi workhorses Trichoderma reesei, Aspergillus niger, and Aspergillus oryzae are well-known for their prominent ability to produce secretory proteins. In addition to these commonly used fungal hosts, there is growing interest in developing non-canonical filamentous fungi such as Humicola insolens [1] and Myceliophthora thermophila [2] as protein producing cell factories.

\footnotetext{
*Correspondence: huanghuoqing@caas.cn; suxiaoyun@caas.cn

1 State Key Laboratory of Animal Nutrition, Institute of Animal Sciences, Chinese Academy of Agricultural Sciences, Beijing 100193, China

Full list of author information is available at the end of the article
}

These fungi are unique in their specialized ability to produce enzymes with intriguing properties, e.g., neutral cellulase from $H$. insolens [3] and thermophilic cellulase from M. thermophila [4]. In T. reesei and Aspergillus spp., many molecular mechanisms governing the gene expression and protein secretion have been deciphered. In contrast, for the former filamentous fungi, the mechanisms underlying protein expression and secretion are poorly known.

Both the prevalent and non-canonical filamentous fungi can be improved by random mutagenesis, which normally introduces many genetic changes to the chromosomes. This is manifested in the original author(s) and the source, provide a link to the Creative Commons licence, and indicate if changes were made. The images or other third party material in this article are included in the article's Creative Commons licence, unless indicated otherwise in a credit line to the material. If material is not included in the article's Creative Commons licence and your intended use is not permitted by statutory regulation or exceeds the permitted use, you will need to obtain permission directly from the copyright holder. To view a copy of this licence, visit http://creativecommons.org/licenses/by/4.0/. The Creative Commons Public Domain Dedication waiver (http://creativeco mmons.org/publicdomain/zero/1.0/) applies to the data made available in this article, unless otherwise stated in a credit line to the data. 
cellulase hyperproducer $T$. reesei RUT-C30 strain: during mutagenesis, the fungus lost a chromosomal region of $85 \mathrm{~kb}$ (29 gene-encoding) among the other mutations [5]. Although the contribution of each mutation to the enhanced cellulase-producing ability has not been clearly defined, it is clear that the improvement is a consequence of cumulative benefits from multiple mutations including the truncation of the transcription repressor cre1 [6] and a frameshift mutation in the glucosidase II involved in glycosylation [7]. Compared with random mutagenesis, rational genetic engineering provides more precise control of protein production. By both means, manipulation of multiple genes, but no single one, is essential in the success towards developing a protein hyperproducer. For example, a mutant strain of RUT-C30 could produce $134 \%$ improved endoglucanase activity. This mutant was generated by integrating two mutations including overexpressing xyr1 (the master transcription activator) and RNAi-mediated gene silencing of ace1 (a transcription repressor)[8]. Despite the advantage of saving time and labor, however, this strategy cannot be used for the fungi with little information about molecular mechanisms regulating secretory protein production.

The past decades have witnessed the successes in genome sequencing of many filamentous fungi as well as in introducing multiple genes into a single filamentous fungal cell such as T. reesei [9], Trichoderma guizhouense [10], and M. thermophila [11]. The availability of sequenced genomes suggests that uncharacterized homologs of known regulatory genes in the prevalent fungi might play similar, orthologous roles in non-canonical filamentous fungi. Additionally, the success in simultaneous transformation of a selected pool of functional genes raised a possibility to manipulate those whose expression impacts secretory protein production. A combination of these two means might serve as an alternative strategy of rational genetic engineering and be particularly useful in filamentous fungi with little knowledge about the regulatory mechanisms. In this way, the possibility of introducing the true effecting regulator(s) could be increased. Additionally, due to the undefined copy numbers and insertion loci in filamentous fungi, combining multiple, but not one, genes in one transformation will create rich diversity in the expression profiles of the targeted genes in the transformants. Therefore, the plethora of expression profiles of the targeted genes would be able to further raise the possibility to generate protein hyperproducers and accelerate the process of strain improvement. This design is essentially semi-rational.

Simultaneous use of pooled functional genes has been successfully used in bacteria [12] and unicellular eukaryotic cells such as S. cerevisiae [13]. However, transformation of pooled functional genes has been seldom reported in filamentous fungi. To demonstrate for proof-of-concept if the semi-rational engineering strategy can be used in filamentous fungi, we chose T. reesei as a model system and tested the strategy to improve its ability to secret cellulase. T. reesei is one of the most important industrial filamentous fungi due to its prominent ability to secrete cellulase as well as heterologous proteins [14]. In $T$. reesei, production of cellulase is affected by several processes involving multiple regulatory stages. We arbitrarily divided secretory production of cellulase in T. reesei into three main stages: Stage 1, transcription; Stage 2 , secretion, including protein folding, transportation, post-translational modification, Endoplasmic reticulumassociated degradation (ERAD), etc., and Stage 3, cell metabolism such as amino acid precursor generation and intracellular redox homeostasis. Firstly, the main regulatory stage is at the transcriptional level, which involves the main activators Xyr1 [15], ACEII [16], and Hap2/3/5 [17], the repressors Cre1 and ACEI, and other newly identified ones [18-20]. Moreover, the secretion pathway, which contains many components such as chaperones, protein foldases, and SNARE proteins, is also important in controlling cellulase production. ERAD is one molecular mechanism that assists $T$. reesei to respond to secretion stress and is responsible for removal of misfolded proteins, thus serving as a quality-control system in protein secretion. Engineering protein folding and transportation can effectively promote secretive protein production in filamentous fungi such as T. reesei [21] and Aspergillus awamori [22]. Protein degradation and glycosylation also affect secretory protein production in the yeasts S. cerevisiae and Pichia pastoris [23, 24]. However, there have been very few studies previously on engineering protein degradation and glycosylation pathways to enhance cellulase production in T. reesei. Therefore, the related putatively functional genes were excellent models of this proof-of-concept analysis and, therefore, included for analysis. Furthermore, one frequently overlooked stage controlling cellulase production in $T$. reesei is the cell metabolism. Production of proteins results in a heavy metabolic burden to the cells, likely leading to a limitation in the supply of amino acids (the building blocks of proteins) and redox equivalents. While biosynthesis of amino acids is a complex metabolic process, both oxidative refolding of disulfide bonds and protein transport through the secretory machinery require energy. Additionally, controlling the redox state in the cytosol and ER is proved to be a prerequisite for efficient folding and secretion of proteins in yeast $[25,26]$. Therefore, in this study, discovered or putatively functional genes within these three stages (transcription, secretion, and cell metabolism) were amplified and cloned into plasmids for overexpression or RNAi-mediated gene silencing. Pooled 
genes within each stage were simultaneously transformed into $T$. reese $i$, the fungus was iteratively evolved using this strategy, and the offspring strains were evaluated for their ability to produce cellulase.

\section{Results}

Designing an iterative semi-rational strategy for stepwise improvement of cellulase production in T. reesei.

The schematic diagram for iterative semi-rational manipulation of multiple selected genes at a time to improve cellulase production in T. reesei is shown in Fig. 1. Briefly, regulation of cellulase production was arbitrarily divided into three main stages. Experimentally verified or predicted activators were overexpressed, while the repressors were silenced for their expression. The plasmids bearing the genes in one same stage were pooled and co-transformed into a $T$. reesei strain (SUS4) with surface-displayed DsRed [27]. Transformant spores or protoplasts were screened for cellulase hyperproducers via fluorescence-assisted cell sorting (FACS, Fig. 1).

For manipulating the first stage which is widely accepted as the main stage of regulation for cellulase production in $T$. reese $i$, two well-studied transcription activators $x y r 1$ and ace 3 , as well as several other candidate regulators genes $(26163,66966,122523$, $80291,64608,123668,74765$, and 27600) that might positively regulate cellulase production were selected as the targets of overexpression [19]. Transcription repressors including cre1 and ace1 were included for RNAi-mediated gene silencing. For the second stage, we integrated the data from other researchers' lab [13] as well as from ours and selected homologous genes of sed1, der 1, ych1, ymr1, och1-2, pep4, doa10, and yps1 as candidate genes for gene silencing. For the third stage, the influence of metabolic flux towards generation of amino acid precursors and redox power on protein expression cannot be ignored in cellulase production. Therefore, we selected three types of genes as candidate genes, including (i) the key genes that contribute to generation of amino acid precursors in the TCA cycle (citrate synthase gene 80621 and isocitrate dehydrogenase gene 52055); (ii) the genes for NADPH production in the pentose phosphate pathway (glucose-6-phosphate dehydrogenase 75769, 6-phosphogluconolactonase 73903, and 6-phosphogluconate dehydrogenase 72685 , for redox balance), and (iii) others such as glutathione reductase gene 53567, for elimination free radicals and the aox1 gene 57940 .

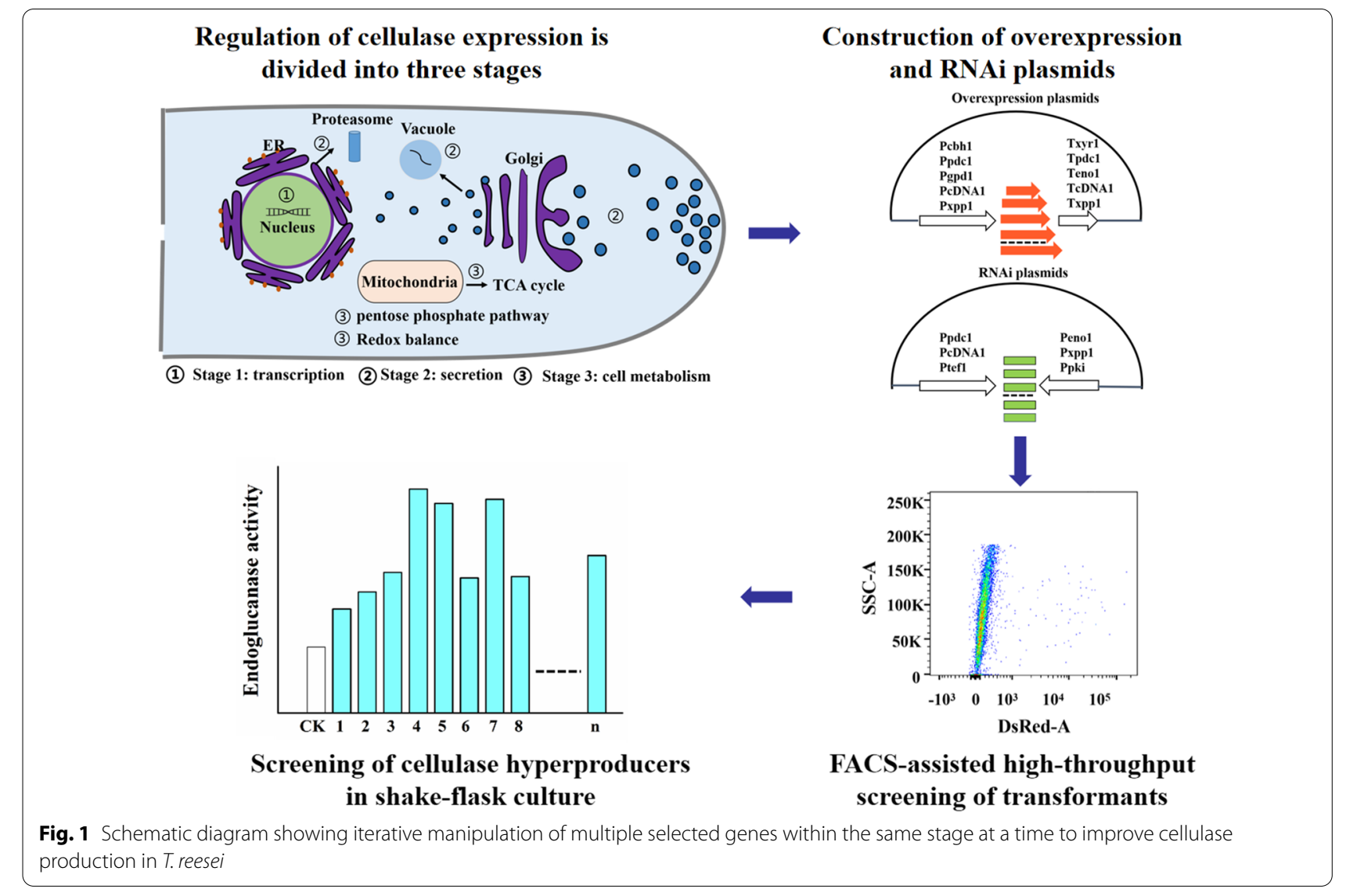




\section{Constructing plasmid pools to regulate cellulase production in $T$. reesei}

All plasmids were constructed by using the Gibson assembly method in this study unless otherwise mentioned. To obtain the plasmids for overexpressing selected candidate genes, intermediate plasmids with six different sets of promoter/terminator were first constructed, which were Ppdc1/Tpdc1, Pgpd1/Teno1, PcDNA1/TcDNA1, Pxpp1/Txpp1, Ppki1/Tcbh1, and Pcbh1/Txyr1. The candidate genes that were thought to work positively were $x y r 1$, ace3, 26163, 66966, 122523, $80291,64608,123668,27600,74765,80621,53567$, $75769,72685,73903,52055$, and 57940 (Table 1). They were individually inserted into one of the plasmids. For gene silencing, three intermediate plasmids with two opposing strong constitutive promoters, i.e., pPpdc1Peno1, pPcDNA1-Pxpp1, and pPtef1-Ppki, were constructed. The candidate genes were ace1, cre1, sed1, der1, ych1, ymr1, och1-2, pep4, doa10 and yps1 which were demonstrated or hypothesized to negatively affect cellulase secretory production (Table 1). They were inserted into the opposing promoters.

\section{Improving T. reesei cellulase production by manipulating the first regulatory stage}

In this study, the T. reesei strain SUS4 displaying the red fluorescence protein DsRed on the cell surface was used as the host strain. In previous studies, we have shown that expression of the DsRed gene directed by the strong inducible $c b h 1$ promoter is positively related to cellulase production [27]. This allowed us to high-throughputly isolate cellulase hyperproducers from its transformants. While xyr1 and ace3 are well-characterized transcription activators, cre 1 and ace 1 are transcription repressors. Additionally, several putatively positively acting transcription factors $(26163,66966,122523,80291$, $64608,123668,74765$ and 27600 ) were selected for testing in this study. In the first trial, the same amount of the

Table 1 The genes selected for use in this study

\begin{tabular}{|c|c|c|c|c|c|c|c|}
\hline Stage & Gene & Verified or predicted functions & $\begin{array}{l}\text { Genetic } \\
\text { manipulation }\end{array}$ & Promoter & Terminator & $\begin{array}{l}\text { Opposed } \\
\text { promoter }\end{array}$ & References \\
\hline \multirow[t]{12}{*}{ 1: transcription } & xyr1 (122208) & Transcription activator, verified & OE & $c b h 1$ & xyr1 & $N / A$ & {$[15]$} \\
\hline & $\operatorname{ace3}(77513)$ & Transcription activator, verified & OE & pdc1 & pdcl & N/A & {$[19]$} \\
\hline & 26163 & Transcription activator, verified & OE & gpd1 & enol & N/A & {$[19]$} \\
\hline & 66966 & Transcription activator, verified & OE & gpd1 & enol & N/A & {$[19]$} \\
\hline & 122523 & Transcription activator, verified & OE & gpd1 & enol & N/A & {$[19]$} \\
\hline & 80291 & Transcription activator, verified & OE & CDNA1 & CDNA1 & N/A & {$[19]$} \\
\hline & 64608 & Transcription activator, verified & OE & CDNA1 & CDNA1 & N/A & {$[19]$} \\
\hline & 123668 & Transcription activator, verified & OE & $x p p 1$ & $x p p 1$ & N/A & {$[19]$} \\
\hline & 27600 & Transcription activator, predicted & OE & xpp1 & $x p p 1$ & $N / A$ & {$[45]$} \\
\hline & 74765 & Transcription activator, verified & OE & xpp1 & $x p p 1$ & $N / A$ & {$[19]$} \\
\hline & $\operatorname{crel}(120117)$ & Transcription repressor, verified & RMGS & CDNA1 & N/A & xpp1 & {$[45]$} \\
\hline & acel (75418) & Transcription repressor, verified & RMGS & CDNA1 & N/A & xpp 1 & {$[58]$} \\
\hline \multirow[t]{8}{*}{ 2: secretion } & sed1 (119975) & Glycosylation, predicted & RMGS & pdcl & N/A & enol & {$[13]$} \\
\hline & $\operatorname{der1}(124187)$ & Protein degradation, verified & RMGS & pdcl & $\mathrm{N} / \mathrm{A}$ & enol & {$[38]$} \\
\hline & $y c h 1(68274)$ & Protein degradation, predicted & RMGS & pdcl & $N / A$ & enol & {$[13]$} \\
\hline & ymr1 (119854) & Protein degradation, predicted & RMGS & tef1 & N/A & $p k i$ & {$[13]$} \\
\hline & och1-2 (80340) & Glycosylation, predicted & RMGS & tef1 & N/A & $p k i$ & {$[13]$} \\
\hline & pep4 (77579) & Protein degradation, verified & RMGS & tef1 & $\mathrm{N} / \mathrm{A}$ & $p k i$ & {$[13]$} \\
\hline & doa10 (123493) & Protein degradation, verified & RMGS & tef1 & $\mathrm{N} / \mathrm{A}$ & $p k i$ & {$[59]$} \\
\hline & yps1 (122076) & Protein degradation, verified & RMGS & CDNA1 & $N / A$ & xpp 1 & {$[13]$} \\
\hline \multirow[t]{7}{*}{ 3:cell metabolism } & 80621 & Amino acid biogenesis, predicted & $\mathrm{OE}$ & gpd1 & enol & $\mathrm{N} / \mathrm{A}$ & {$[60]$} \\
\hline & 52055 & Amino acid biogenesis, predicted & OE & pki & cbh2 & N/A & {$[61]$} \\
\hline & 53567 & Free radical elimination, predicted & $\mathrm{OE}$ & CDNA1 & CDNA1 & $N / A$ & {$[62]$} \\
\hline & zWf1 (75769) & NADP/NADPH balance, verified & $\mathrm{OE}$ & CDNA1 & CDNA1 & $\mathrm{N} / \mathrm{A}$ & {$[37]$} \\
\hline & 72685 & NADP/NADPH balance, verified & $\mathrm{OE}$ & CDNA1 & CDNA1 & $\mathrm{N} / \mathrm{A}$ & {$[37]$} \\
\hline & 73903 & NADP/NADPH balance, verified & $\mathrm{OE}$ & pki & cbh2 & N/A & {$[26]$} \\
\hline & $\operatorname{aox} 1(57940)$ & NAD/NADH balance, verified & OE & xpp1 & xpp 1 & N/A & {$[47]$} \\
\hline
\end{tabular}


plasmids for manipulating the first regulatory stage were mixed with a pyr4-expressing cassette [28] and used for SUS4 transformation. The transformants were inoculated on PDA plates for sporulation. The transformant spores were pooled and cultured with shaking for $13 \mathrm{~h}$ in liquid MM-lactose/sophorose medium. Flow cytometry analysis indicated that some of the transformants had remarkably higher red fluorescence signal than SUS4 (Fig. 2A). Twenty-seven transformants with highest red fluorescence were collected for sporulation. Germinated spores were cultured in the liquid cellulase-inducing medium for assay of cellulase activity. On day 5 post-cellulose induction, the cellulase activity as indicated by endoglucanase of most sorted mutants was higher than that of the parent strain in a preliminary screening (Fig. 2B). Five representative strains were chosen for further analysis of cellulase production and they were determined to indeed produce higher levels of cellulase (Fig. 2C) and extracellular proteins (Fig. 2D). On day 5 post-cellulose induction, compared with SUS4 $(13.5 \mathrm{U} / \mathrm{ml}$ as the highest activity), the endoglucanase activity of the five strains increased to maxima of 26.7-32.3 $\mathrm{U} / \mathrm{ml}$, and the extracellular protein concentration reached to maxima of $0.21-0.25 \mathrm{mg} / \mathrm{ml}$, which was approximately twice that of SUS4.

\section{Analyzing the integrated transcription regulatory genes in the representative transformants}

The five representative strains $(1-2,1-3,1-13,1-25$, and 1-31) and the parental strain SUS4 were used for extraction of genomic DNA and PCR amplification of the transformed DNA inserts. For the 12 selected genes, gene-specific primers were designed in positions located between the promoter and the gene or those between the gene and the terminator in the plasmids, with an expected size of amplification of $\sim 500$-bp (Fig. 2E). In the parental strain SUS4, there was no band corresponding to any of the 12 constructs. However, in all the transformants, there were either one or multiple DNA bands corresponding to the expected sizes of ace3, xyr1, 26163, $66966,64608,27600$, and 74765 (Fig. 2E). For the representative transformant 1-2, 5 genes (ace3, xyr1, 26163, 66966, and 27600) were introduced; for 1-3 and 1-13, two different sets of genes including ace3, xyr1, 66966, and 74765 or ace3, xyr1, 66966, and 27600 were inserted in the genome; for 1-25 and 1-31, two different sets each containing three genes (i.e., "xyr1, 26163, and 66966" and "xyr1, 26163, and 64608") were introduced. Interestingly, all these transformants were introduced with the xyr 1 transcription activator gene. In addition, the relative transcript levels of the inserted genes in representative transformants were assayed. The transcript levels of these genes in SUS4 at $24 \mathrm{~h}$ post-induction were arbitrarily set as 1.0. The transcript abundance of almost all the inserted genes was significantly increased. The transcription of xyr1, ace $3,26163,66966$, and 27600 of 1-2 increased by $13.5 \pm 1.1-, 2.9 \pm 0.3-, 2.9 \pm 0.2-, 10.4 \pm 1.7-$, and $3.2 \pm 0.1-$ fold, respectively (Table 2). For some genes in specific transformants, there was no significant change, such as 66966 in 1-3, 26163 in 1-25, and 64608 in 1-31.

\section{Manipulating expression of selected genes in Stage 2}

The 1-2 representative transformant was selected to test if simultaneous manipulating expression of multiple genes involved in the secretion pathway would similarly improve cellulase production. The two direct repeats flanking pyr4 enabled us to rapidly loop out the selection marker gene of this strain by placing the spores of the strain on minimal medium plates.

Previously we demonstrated that overexpressing chaperone or SNARE genes in the secretion pathway can significantly improve cellulase [27] as well as heterologous protein [21] production. Herein, for regulation of Stage 2, we instead silenced genes (sed1, der1, ych1, ymr1, och1-2, pep4, doa10 and yps1) associated with the glycosylation and ERAD process. These genes included those encoding the intracellular proteases that are proposed to be involved in quality control of folding of secretory proteins. The uridine auxotroph mutant of strain 1-2 (named 1-2/Apyr4) with nearly identical cellulase-producing ability to that of strain 1-2 was transformed with a pool of plasmids silencing these candidate genes in regulatory Stage 2. Unfortunately, in the initial trials when using germinated spores for FACS analysis, the transformants displayed nearly identical red fluorescence signal to that of 1-2/Apyr4 (Fig. 3A).

Since most of the selected genes were involved in protein secretion such as glycosylation and intracellular protein degradation, we hypothesized that the induction time as short as $13 \mathrm{~h}$ for the germinated spores may not be long enough for differentiating the red fluorescence. Therefore, the mixed spores were cultured for an extended period of $72 \mathrm{~h}$ when protein began to be largely secreted and the mycelia were enzymatically treated for protoplast releasing. With this modification, part of the transformed protoplasts displayed higher red fluorescence signal than 1-2/Apyr4 in FACS analysis (Fig. 3A). The survival rate of individual protoplasts ranged from 30 to $40 \%$. On day 5 post-cellulose induction in shakeflask cultivation, all sorted transformants showed higher endoglucanase activity than 1-2/Apyr4 (Fig. 3B). Five representative strains displayed higher ability to produce cellulase (Fig. 3C) and extracellular proteins (Fig. 3D) in this flask cultivation. Compared with the parent strain $1-2 / \Delta$ pyr4 $(26.0 \mathrm{U} / \mathrm{ml})$, the endoglucanase activity of 
A

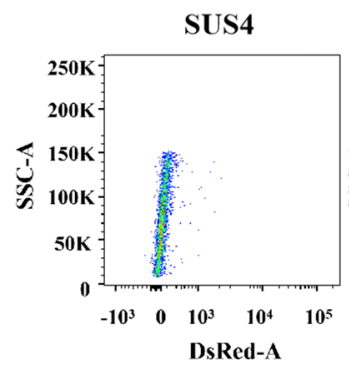

C

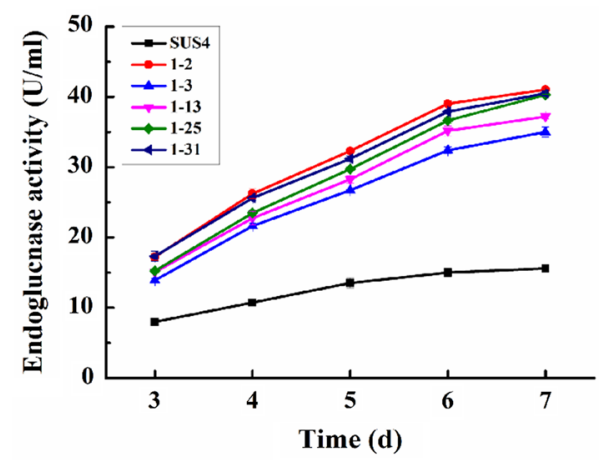

E

Verification of overexpressed gene insertion
B

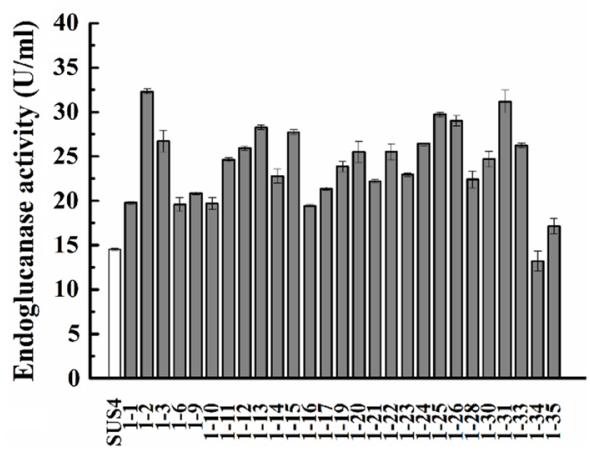

D

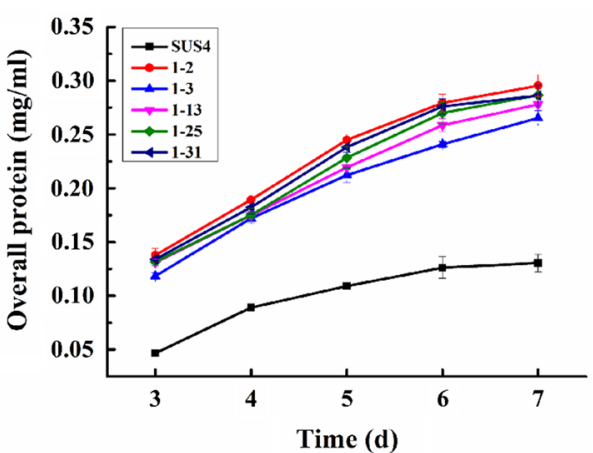

Verification of RNAi gene insertion

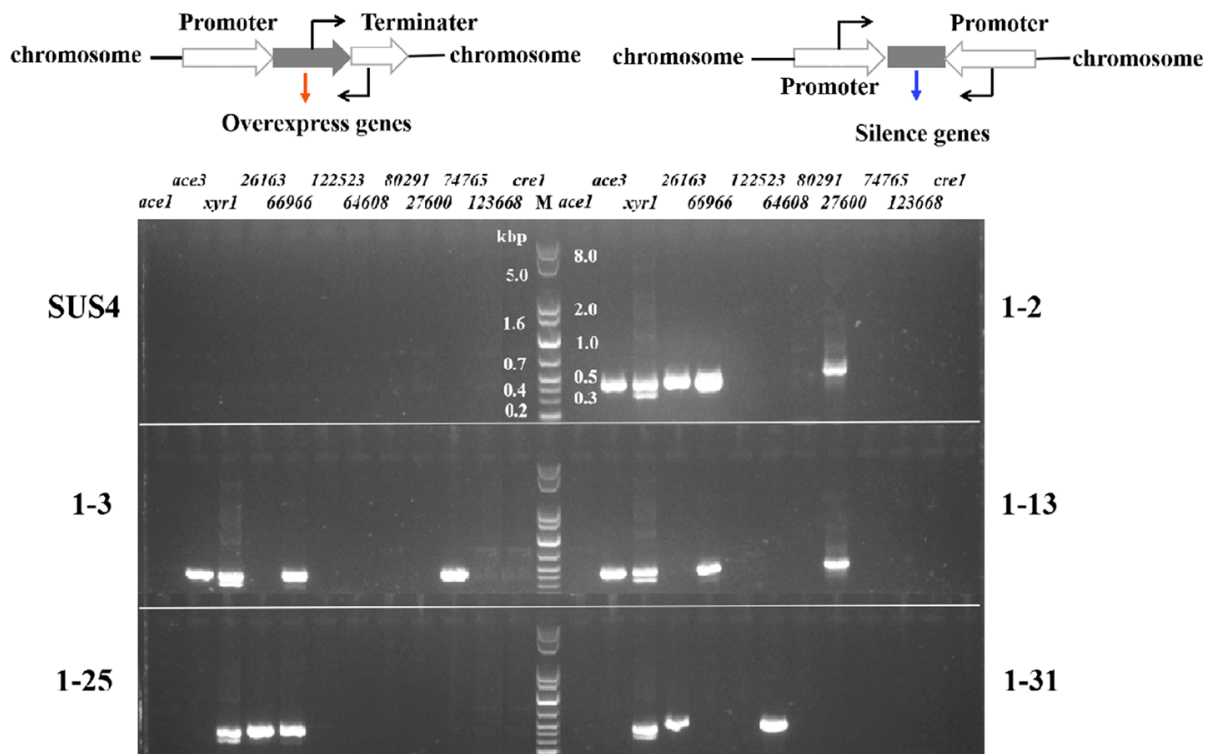

Fig. 2 Manipulating Stage 1 to improve cellulase production. A Analysis of the transformant spores in FACS. The box indicated the spore sampling. B An initial screening of endoglucanase activity in the selected transformants on day 5 post-cellulase induction. $\mathbf{C}$ and $\mathbf{D}$ Production of endoglucanase $(\mathbf{C})$ and extracellular protein concentration $(\mathbf{D})$ of the transformants. E Determining integration of the transformed genes 
Table 2 The relative transcript abundance of transformed genes*

\begin{tabular}{|c|c|c|c|c|c|c|c|}
\hline Stage & Gene & Parental strain & $\begin{array}{l}\text { Representative } \\
\text { transformants }\end{array}$ & & & & \\
\hline \multirow[t]{8}{*}{ 1: transcription } & & SUS4 & $1-2$ & $1-3$ & $1-13$ & $1-25$ & $1-31$ \\
\hline & ace3 & 1.0 & $2.9 \pm 0.3$ & $2.2 \pm 0.2$ & $3.6 \pm 0.2$ & N.D & N.D \\
\hline & xyr1 & 1.0 & $13.5 \pm 1.1$ & $8.6 \pm 0.6$ & $7.6 \pm 0.6$ & $8.8 \pm 1.1$ & $9.5 \pm 0.7$ \\
\hline & 26163 & 1.0 & $2.9 \pm 0.2$ & N.D & N.D & $1.1 \pm 0.1$ & $5.8 \pm 0.6$ \\
\hline & 66966 & 1.0 & $10.4 \pm 1.7$ & $1.0 \pm 0.2$ & $17.0 \pm 1.2$ & $2.1 \pm 0.3$ & N.D \\
\hline & 27600 & 1.0 & $3.2 \pm 0.1$ & N.D & $10.5 \pm 0.3$ & N.D & N.D \\
\hline & 74765 & 1.0 & N.D & $8.3 \pm 0.4$ & N.D & N.D & N.D \\
\hline & 64608 & 1.0 & N.D & N.D & N.D & N.D & $1.0 \pm 0.1$ \\
\hline \multirow[t]{9}{*}{ 2: secretion } & & $1-2 / \Delta$ pyr4 & $2-3$ & $2-4$ & $2-13$ & $2-18$ & $2-29$ \\
\hline & sed1 & 1.0 & $0.3 \pm 0.0$ & $1.4 \pm 0.1$ & $0.4 \pm 0.1$ & $0.6 \pm 0.1$ & $0.2 \pm 0.1$ \\
\hline & der1 & 1.0 & $1.5 \pm 0.2$ & $0.6 \pm 0.1$ & $0.8 \pm 0.1$ & $1.5 \pm 0.2$ & $0.9 \pm 0.0$ \\
\hline & $y c h 1$ & 1.0 & $1.1 \pm 0.1$ & $1.5 \pm 0.2$ & $1.5 \pm 0.1$ & $0.4 \pm 0.1$ & $0.9 \pm 0.1$ \\
\hline & $y m r 1$ & 1.0 & $0.3 \pm 0.1$ & $0.3 \pm 0.1$ & $0.2 \pm 0.0$ & $0.5 \pm 0.1$ & $0.7 \pm 0.2$ \\
\hline & och1-2 & 1.0 & $1.1 \pm 0.2$ & $1.2 \pm 0.1$ & $0.4 \pm 0.1$ & $0.3 \pm 0.0$ & $0.2 \pm 0.0$ \\
\hline & pep4 & 1.0 & $0.2 \pm 0.1$ & $0.8 \pm 0.1$ & $0.8 \pm 0.2$ & $0.8 \pm 0.1$ & $0.7 \pm 0.1$ \\
\hline & doa10 & 1.0 & $0.6 \pm 0.1$ & $0.8 \pm 0.1$ & $1.6 \pm 0.3$ & $0.9 \pm 0.1$ & $1.2 \pm 0.2$ \\
\hline & yps 1 & 1.0 & $0.3 \pm 0.1$ & $0.8 \pm 0.1$ & $0.7 \pm 0.1$ & $1.7 \pm 0.2$ & $1.3 \pm 0.1$ \\
\hline \multirow[t]{8}{*}{ 3: cell metabolism } & & $2-3 / \Delta$ pyr4 & $3-2$ & $3-4$ & $3-8$ & $3-18$ & $3-25$ \\
\hline & 80621 & 1.0 & $1.1 \pm 0.2$ & $2.3 \pm 0.2$ & $1.1 \pm 0.1$ & $1.2 \pm 0.1$ & $0.9 \pm 0.2$ \\
\hline & 52055 & 1.0 & $2.1 \pm 0.3$ & $0.9 \pm 0.1$ & $1.3 \pm 0.2$ & $1.1 \pm 0.1$ & $1.2 \pm 0.0$ \\
\hline & 53567 & 1.0 & $2.0 \pm 0.2$ & $1.3 \pm 0.1$ & $2.9 \pm 0.3$ & $2.3 \pm 0.1$ & $1.2 \pm 0.1$ \\
\hline & 75769 & 1.0 & $2.3 \pm 02$ & $1.1 \pm 0.1$ & $5.0 \pm 0.3$ & $2.4 \pm 0.2$ & $1.3 \pm 0.1$ \\
\hline & 72685 & 1.0 & $8.6 \pm 0.2$ & $3.0 \pm 0.2$ & $4.0 \pm 0.2$ & $4.1 \pm 0.4$ & $6.5 \pm 0.2$ \\
\hline & 73903 & 1.0 & $2.4 \pm 0.3$ & $1.1 \pm 0.0$ & $2.7 \pm 0.1$ & $2.6 \pm 0.2$ & $1.6 \pm 0.1$ \\
\hline & 57940 & 1.0 & $2.9 \pm 0.1$ & $0.7 \pm 0.2$ & $0.5 \pm 0.1$ & $0.8 \pm 0.1$ & $0.9 \pm 0.0$ \\
\hline
\end{tabular}

${ }^{*}$ All experiments were performed in three independent replicates

N.D. not determined

the five representative strains was increased to $37.4 \mathrm{U} /$ $\mathrm{ml}(2-4) \sim 46.2 \mathrm{U} / \mathrm{ml}(2-3)$ on day 5 post-induction (Fig. 2C). Not surprisingly, the overall extracellular protein of these transformants reached maximal concentration of $0.26 \sim 0.30 \mathrm{mg} / \mathrm{ml}$, higher than $0.21 \mathrm{mg} / \mathrm{ml}$ for $1-2 / \Delta$ pyr4.

From the RT-qPCR analysis, decreased expression of the functional genes was observed in each of the representative transformant (Table 2). For example, the relative transcript levels of sed 1, ymr1, pep4, doa10, and yps1 in strain 2-3 were much lower than those in $1-2 / \Delta \mathrm{pyr} 4$, decreasing to $0.3 \pm 0.0-, 0.3 \pm 0.1-, 0.2 \pm 0.1-, 0.6 \pm 0.1$-, and $0.3 \pm 0.1$-fold, respectively. Repressed expression of $y m r 1$, but not the others, was observed in all five offspring strains.

\section{Manipulating expression of selected genes in Stage 3 for further improved cellulase production}

Strain 2-3 was selected for further engineering. The pyr4 auxotrophic mutant of strain 2-3 was prepared and introduced with plasmids for overexpressing the seven genes (80621-citrate synthase, 52055-isocitrate dehydrogenase, 53567-glutathione reductase, 75769-glucose-6-phosphate dehydrogenase, 72685-6-phosphogluconate dehydrogenase, 73903-6-gluconolactonase, and 57940-alternative oxidase) targeting stage 3 for regulation (Table 1). FACS analysis of the protoplasts, rather than the germinated spores, indicated that there were transformants with stronger red fluorescence than the direct parental strain 2-3/Spyr4 (Fig. 4A). Part of the sorted transformants showed higher cellulase activity than 2-3/4pyr4 (Fig. 4B). The cellulase activities of five selected transformants topped at 47.4 (for 3-4)-57.5 (for 3-8) $\mathrm{U} / \mathrm{ml}$, significantly higher than that of strain $2-3 /$ spyr4 $(35.7 \mathrm{U} / \mathrm{ml})$ on day 
A

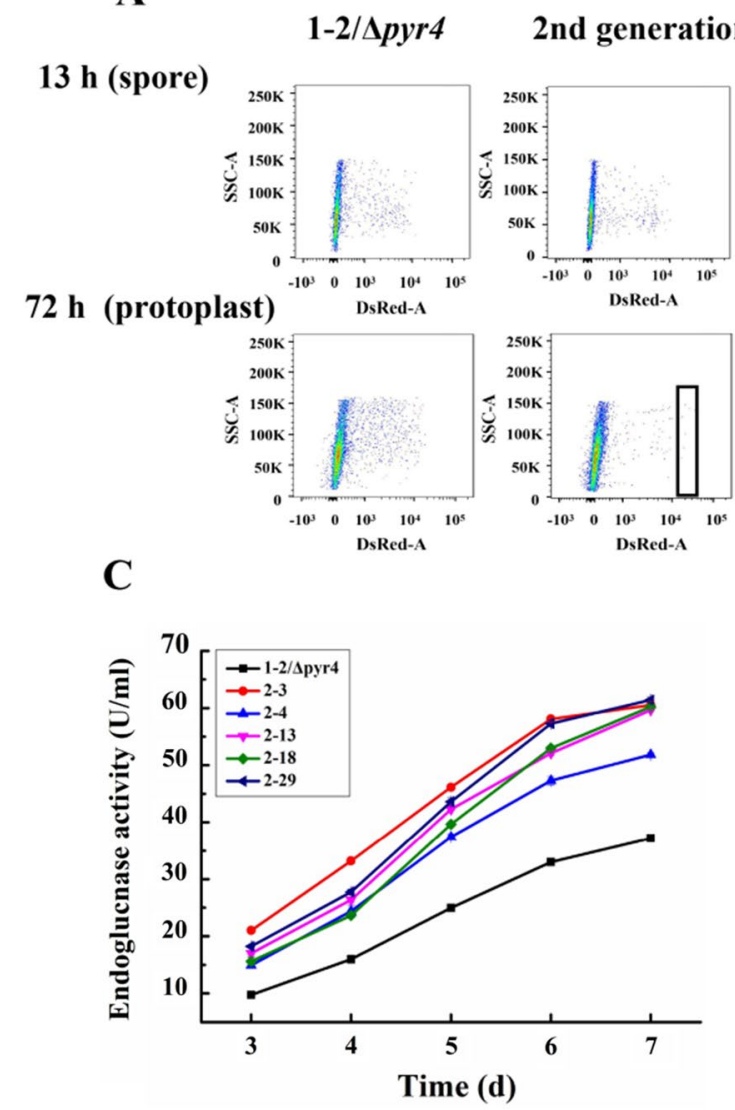

B

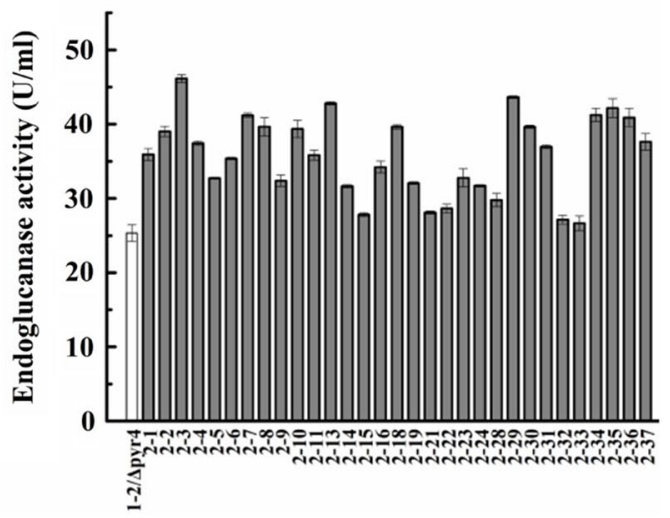

D

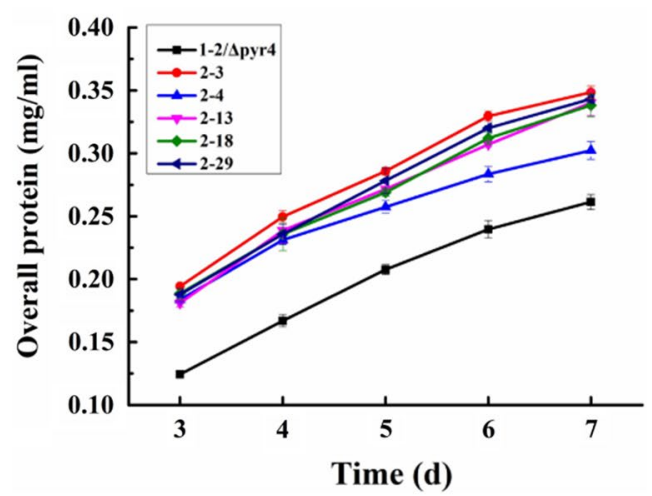

Fig. 3 Manipulating Stage 2 to improve cellulase production. A FACS analysis of the transformant spores at $13 \mathrm{~h}$ post-induction or protoplasts prepared from the transformant mycelia at $72 \mathrm{~h}$ post-induction. The box indicated the protoplast sampling. B An initial screening of endoglucanase activity in the selected transformants on day 5. C and D. Production of endoglucanase (C) and extracellular protein concentration (D) of the transformants

5 post-cellulose induction (Fig. 4C). The extracellular protein concentrations of the five representative strains ranged in $0.28 \sim 0.33 \mathrm{mg} / \mathrm{ml}$, also higher than that of the parent strain 2-3/Spyr4 (0.25 mg/ml) (Fig. 4D).

In the RT-qPCR analysis, the relative transcript levels of genes 53567, 75769, 72685, and 73903 in the 3-8 transformant were $2.9 \pm 0.3-, 5.0 \pm 0.3-, 4.0 \pm 0.2-$, and $2.7 \pm 0.1$-fold that of strain 2-3/Apyr4 (Table 2). Interestingly, the pentose phosphate pathway, particularly the gene 72685 appeared to be enriched in the selected transformants.

\section{Expression of cellulase genes in WT and the $1 \mathrm{st}, 2 \mathrm{nd}$, and 3rd generation transformants}

Among the three selected stage transformants, 1-2, 2-3, and 3-8 transformants with comparably higher endoglucanase activity were selected as representative strains of the 1st, 2nd and 3rd round manipulation of transformants, respectively. The increase in cellulase production could be visualized on an SDS-PAGE gel of 1-2, 2-3, and 3-8 transformants on day 5 post-cellulose induction (Additional file 1: Figure S2). The relative transcript level of cbh1, cbh2, eg1, eg2, and xyr1 of WT cultured for $24 \mathrm{~h}$ in the cellulase-inducing medium was arbitrarily set as 1.0. Clearly, the relative transcript levels of $c b h 1$, cbh2, eg1, eg2, and xyr1 of 1-2 were much higher in the genetically engineered strains than those of WT, increasing by 10.9-fold, 4.4-fold, 6.4-fold, 9.5-fold, and 13.5-fold, respectively (Fig. 5A).

We also noticed that the intracellular protein concentrations (as a reflection of the mycelia biomass) of the engineered strains were slightly higher than that of the WT strain SUS4 (Fig. 5B). For example, on day 5 postcellulose induction, the intracellular proteins of WT, $1-2,2-3$, and $3-8$ were $0.32,0.35,0.40$, and $0.41 \mathrm{mg} / \mathrm{ml}$, respectively. However, the larger amount of biomass cannot account for all the increments in cellulase-producing ability. The normalized endoglucanase activity against 


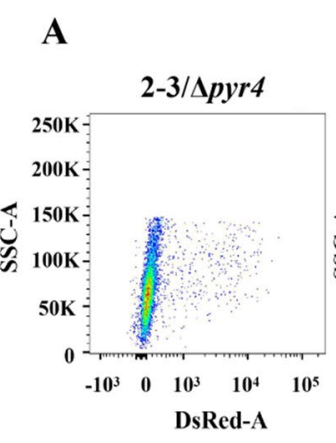

C

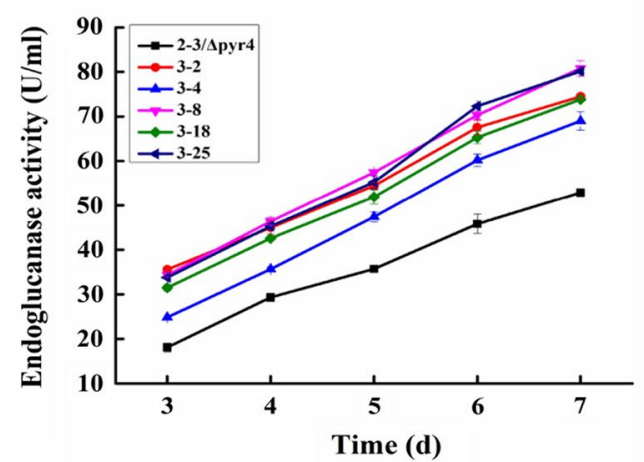

B
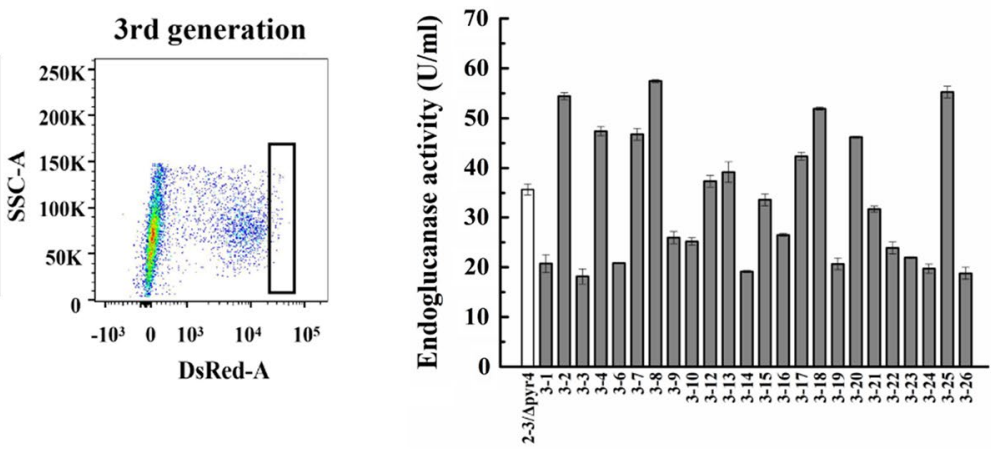

D

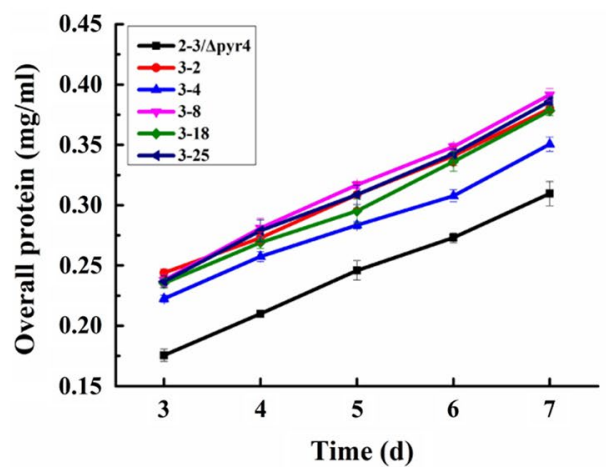

Fig. 4 Manipulating Stage 3 to improve cellulase production. A FACS analysis of the protoplasts prepared from the transformant mycelia at $72 \mathrm{~h}$ post-cellulase induction. The box indicated the protoplast sampling. B An initial screening of endoglucanase activity in the selected transformants on day 5. $\mathbf{C}$ and $\mathbf{D}$ Production of endoglucanase $(\mathbf{C})$ and extracellular protein concentration $(\mathbf{D})$ of the transformants
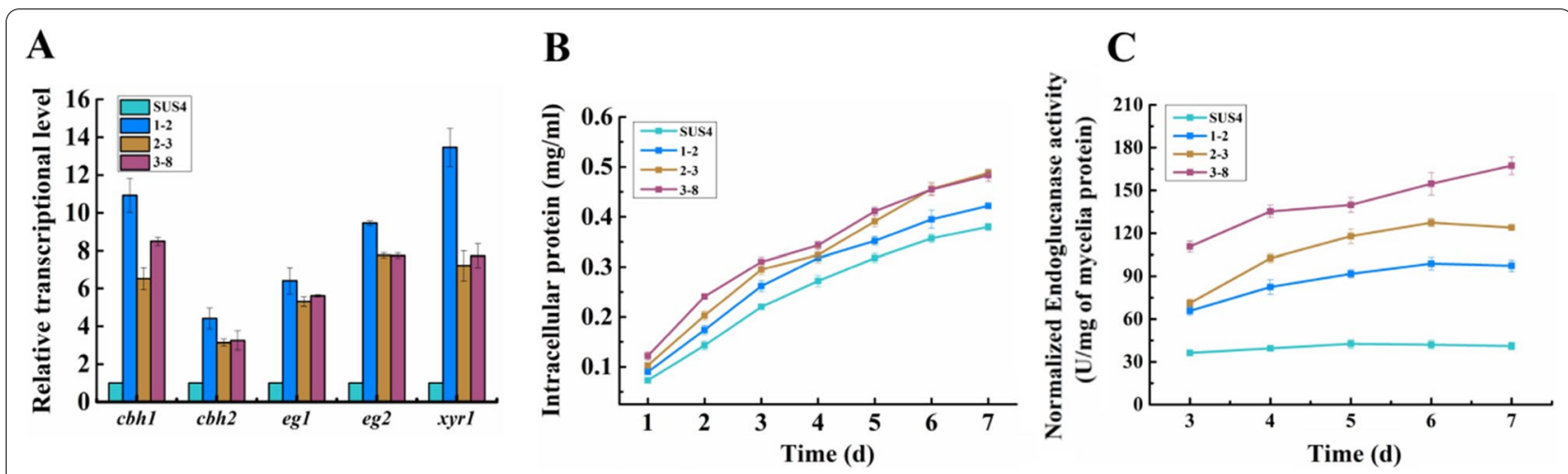

Fig. 5 Comparison of cellulase production in WT and three representative strains. A Relative transcript levels of the main cellulase genes cbh1, cbh2, eg/1, eg/2 and the master transcription activator $x y r 1$, which were determined at $24 \mathrm{~h}$ post-cellulase induction. $\mathbf{B}$ Intracellular protein concentrations (as a reflection of the mycelial biomass) of the transformants. C Normalized endoglucanase activity against fungal biomass

mycelial biomass in $1-2,2-3$, and 3-8 all increased when comparing to their parental strains (Fig. 5C). For example, on day 5 post-cellulose induction, the normalized endoglucanase activity of SUS4, 1-2, 2-3, and 3-8 were $42.6,91.8,117.9$, and $139.8 \mathrm{U} / \mathrm{mg}$, respectively.
Therefore, the improvement of cellulase-producing ability of the engineered strains was a combinatorial effect of increments in the specific cellulase-production rate and growth rate. 


\section{Discussion}

Strain improvement is critical to modern biotechnology and multiple rounds of engineering are often demanded for development of a highly efficient protein production strain. In this study, we used T. reesei as a model filamentous fungus and demonstrated as a proof-of-concept that genes within an arbitrarily defined regulatory stage could be pooled to stimulate secretory protein production, and moreover, this method could be iteratively used for evolving an even higher ability of protein production. This strategy is semi-rational, which essentially does not rely on established understanding of the deliberate regulatory mechanisms of secretory protein expression. Indeed, as demonstrated in Stage 2 and 3 , when the regulation is not clear in emerging noncanonical filamentous fungal hosts such as in $\mathrm{H}$. insolens and M. thermophila, one can learn from the other organisms whose mechanisms have been elucidated and accordingly use the homologous genes for evolution. In our study, RNAi was used to silence expression of repressors. RNAi was well-known to lead to varying levels of targeted gene suppression [29], thereby further extending the diversity in the transcript levels of selected genes. The RNAi machinery components appear to be universal in many filamentous fungi [30] and thus can be similarly employed in the semi-rational evolution.

Manipulation of the transcription stage led to the most significant improvement. The cellulase activity increased to up to 2.4-fold and the protein concentration increased to up to 2.3-fold. This is in accordance with the notion that cellulase induction in $T$. reesei is mainly regulated at the transcription level [31]. The predominant presence of the master transcription activator $x y r 1$ transcript indicated that overexpression of $x y r 1$ played a major role in the cellulase hyperproducer strains. However, when xyr 1 was individually transformed in SUS4, the cellulase activity and extracellular protein concentration of three representative transformants increased by $1.6 \sim 1.7$-fold and 1.5-fold, respectively (Additional file 1: Figure S1A, B), which were much smaller than those obtained by cotransformation of $x y r 1$ and other selected genes. The normalized cellulase activity against mycelial biomass was also increased in the transformants (Additional file 1: Fig. $\mathrm{S1C})$. In the three xyr1-overexpressing transformants, the $x y r 1$ transcript level increased to a level (8.7 10.6-fold) similar to those strains obtained in manipulating Stage 1 (Additional file 1: Fig. S1D). The results suggested that combining specific groups of genes might be superior to manipulating just one master regulator. However, we cannot exclude the possibility that in the co-transformed genes, there could be one or more that either did not impact or even negatively affected cellulase expression.
Unexpectedly, although the well-characterized transcription activator gene ace 3 was detected in three of the transformants, 66966 was discovered in four of them and overexpressed in three. This strongly suggested that gene 66966 might act to stimulate cellulase transcription in $T$. reesei. The gene 66966 was selected from the transcriptomics data because the cellulase activity of a strain overexpressing this gene was more than 1.5 times that of the parent strain and predicted to encode a conserved WD40 repeat-containing protein with unknown functions [19]. WD40 proteins play important roles in a variety of cellular functions including signal transduction, chromatin remodeling, and transcriptional regulation [32]. In addition, although overexpression of the gene 26163 (the homologue of $c l r-2$ ) did not lead to significant improvement in cellulase production in T. reesei QM9414 [19], its transcript level significantly increased in 1-2 and $1-31$. In the genome, the gene is located close to a sugar transporter, which is considered to be a lactose permease essential for induction of $c b h 1$ and $c b h 2$ [33]. However, the contribution of this gene to improved cellulase activity, especially in a strain with a genetic background different from QM9414, remains to be elucidated.

We further discovered that in all stages (Stage 1-3) a certain selected gene(s) were prevalent in the selected representative transformants. For example, $x y r 1$ appeared in all five Stage 1 transformants, $y m r 1$ was observed in four of the five Stage 2 transformants, and gene 72685 was present in all five Stage 3 transformants. Since $x y r 1$ is a main transcriptional activator that regulates cellulase production, it is not surprising that $x y r 1$ appeared in all five Stage 1 transformants. ymr 1 (yeast myotubularinrelated phosphatase) is a myotubularin family member and has a direct role in regulation of phosphatidylinositol 3-phosphate-dependent signaling pathways [34]. It has been reported that phosphatidylinositol 3-phosphate serves as a key regulator of vesicular trafficking within the endosomal system [35]. Therefore, interfering with $y m r 1$ expression may affect protein translocation from late Golgi apparatus to the vacuole, thus affecting cellulase secretion. The gene 72685 (6-phosphogluconate dehydrogenase) is a key regulator in the pentose phosphate pathway, a catabolic pathway known to produce NADPH. NADPH is known to be an important cofactor ensuring intracellular redox balance [36]. The gene 72685 was present in all five Stage 3 transformants, suggesting that alteration of the pentose phosphate pathway could change the metabolic flux and further fine-tune the intracellular redox balance. These results were consistent with the reports that overexpressing gndA gene (6-phosphogluconate dehydrogenase) in $A$. niger can increase the yield of glucoamylase [37]. Therefore, it would be particularly intriguing to investigate whether and how 
these genes can stimulate cellulase gene expression and whether they can interact, either physically or genetically, with other known regulators responsible for cellulase production.

The obtaining of improved transformants in manipulating Stage 2 suggested that the poorly understood ERAD might not be perfect. As a result, attenuating this pathway appeared to counteract this quality-control mechanism and in future, may be used in combination with overexpressing the ER-resident chaperones for enhancing secretory protein production [21]. Carvalho reported that, in A. niger, disruption of the ERAD pathway genes increased the intracellular concentration of the glucoamylase-glucuronidase (GlaGus) fusion reporter protein. However, the extracellular GlaGus appeared not to be increased [38]. Two reasons might account for the observed inability to improve protein secretion in $A$. niger. First, secreted GlaGus might be vulnerable to the $A$. niger extracellular proteases. Second, GlaGus in A. niger and cellulase in $T$. reesei likely require different transporting component proteins in the secretion pathway.

The finding that manipulating gene expression in Stage 3 could stimulate cellulase gene expression is encouraging. Note that, based on the same hypothesis as that for Stage 2, we utilized protoplasts instead of spores to screen for the cellulase hyperproducers. Improvement of cellulase-producing ability from Stage 2 to Stage 3 indicated that a fine-tuning of the interior cellular metabolism and redox state is required for efficient cellulase production. Since it had been proved that multiple genes could be integrated in the chromosome in Stage 1 , investigation by PCR of the selected genes in Stage 2 and 3 was not carried out further. However, the success in stimulating more cellulase production may prompt more mechanistic investigations to be placed in how cellular metabolism can influence cellulase production in $T$. reesei. The transcription of genes involved in the pentose phosphate pathway (e.g., gene 72685) was significantly enhanced in selected transformants, likely reflecting the important influence of NADP/NADPH balance on protein production. Indeed, several studies have already shown that fine-tuning the metabolic balance through change of the pentose phosphate pathway can improve heterologous protein expression, such as in Pichia pastoris [39] and A. niger [40].

Unexpectedly, the relative transcript levels of main cellulase (cbh1, cbh2, eg1, and eg2) and xyr1 genes of 2-3 and 3-8 were lower than (but still comparable to) those of 1-2. This could be due to other unidentified mutations in the genome when trying to obtaining the pyr4- recipient strains. However, the possibility that altered gene expression at Stage 2 and 3 may affect cellulase production cannot be excluded. In manipulating functional genes in Stage 2, while more proteins might be retained in the endoplasmic reticulum and translocated to the Golgi apparatus, this led to an interference with the secretory pathway. Impairment of the pathway is known to be able to decrease expression of major cellulase genes through a mechanism known as repression under secretion stress (RESS) [41]. In addition, change of cell metabolism and redox state can also affect transcription of secretory protein. For example, in rat, repressing the function of isocitrate dehydrogenase-2 (IDH2, catalyzing reductive carboxylation of 2-ketoglutarate to isocitrate) lowered the NADPH level and inhibited insulin secretion $[42,43]$. Such information, together with the impairment in cellulase production in knocking out pyr4, might account for the observation that transcription of some cellulase genes were less abundantly transcribed in the Stage 2 and 3 stains.

In modern strain engineering, robot-based automation such as biofoundry appears to be more and more involved. Due to its high efficiency, this technology deals often with strains from pooled genes in metabolic pathways (such as mutant libraries from directed evolution) transformation with highly diversified background [44]. Therefore, the success in T. reesei suggests that the semirational strategy may, as in unicellular microbes, also be used in filamentous fungi in robot-based high-throughput strain improvement. Importantly, the current study clearly pinpoints the possibility of using this method in emerging filamentous fungi hosts with little knowledge regarding regulation of protein secretion.

\section{Conclusions}

In this study, we arbitrarily divided cellulase production in $T$. reesei in three main stages (transcription, secretion, and cell metabolism). Functionally validated or predicted functional genes potentially operating at the same stage were selected and co-transformed into the recipient $T$. reesei strains. We could demonstrate as a proof-of-concept that genes within an arbitrarily defined regulatory stage could be pooled to stimulate secretory cellulase production, and moreover, this method could be iteratively used. This strategy could also be used in filamentous fungi with poor knowledge about expression of secretory proteins.

\section{Methods}

\section{Strains and plasmids}

The Escherichia coli Fast-T1 strain from Vazyme (Nanjing, China) was used throughout this study for plasmid construction and propagation. E. coli was cultured in Luria-Bertani (LB) medium supplemented with an appropriate antibiotic if needed. The mutant strain $T$. reesei SUS4 expressing DsRed on its cell surface [27] is a 
uridine auxotroph of SUS1 and was used as the recipient strain in this study. SUS1 is a mutant of QM9414 developed in our lab after multiple rounds of mutagenesis with an enhanced cellulase-producing ability and lower viscosity [28]. All T. reesei strains were maintained on potato dextrose agar (PDA) at $28^{\circ} \mathrm{C}$ for sporulation. For enzyme production, the $T$. reesei strains were grown in a minimal medium (MM) containing $\left(\mathrm{NH}_{4}\right)_{2} \mathrm{SO}_{4}, 5.0 \mathrm{~g} / \mathrm{L} ; \mathrm{KH}_{2} \mathrm{PO}_{4}$, $15 \mathrm{~g} / \mathrm{L} ; \mathrm{MgSO}_{4}, 0.6 \mathrm{~g} / \mathrm{L} ; \mathrm{CaCl}_{2}, 0.6 \mathrm{~g} / \mathrm{L} ; \mathrm{FeSO}_{4} \cdot 7 \mathrm{H}_{2} \mathrm{O}$, $0.005 \mathrm{~g} / \mathrm{L} ; \quad \mathrm{MnSO}_{4} \cdot \mathrm{H}_{2} \mathrm{O}, 0.0016 \mathrm{~g} / \mathrm{L} ; \quad \mathrm{ZnSO}_{4} \cdot 7 \mathrm{H}_{2} \mathrm{O}$, $0.0014 \mathrm{~g} / \mathrm{L} ; \mathrm{CoCl}_{2}, 0.002 \mathrm{~g} / \mathrm{L}$. MM was supplemented with glucose (2\%) for mycelial growth or Avicel crystalline cellulose (2\%) for cellulase induction.

\section{Selection of functional genes for simultaneous transformation}

Expression of cellulase in $T$. reesei is affected by multiple regulatory stages. Based on literatures and publicly available transcriptomic data, the following candidate genes involved in transcription, secretion, and metabolism were selected. The well-characterized transcription activators $x y r 1$, ace 3 , and several putative transcription factors including gene 26163, 66966, 122523, 80291, $64608,123668,74765$ [19], the and 27600 [45] that may act positively were selected for overexpression. In addition, the known transcription repressors cre 1 and ace1 were chosen for RNAi-mediated gene silencing. Several genes (sed1, der1, ych1, ymr1, och1-2, pep4, doa10 and yps1) involved in protein secretion in S. cerevisiae. These genes mainly involved in the ERAD process were selected for RNAi-mediated gene silencing. The cellular metabolism is regarded to have strong impact on synthesis of secreted proteins. Therefore, genes including 80621 (citrate synthase gene), 52055 (isocitrate dehydrogenase gene), 53567 (glutathione reductase gene), 75,769 (glucose-6-phosphate dehydrogenase gene, zwf1)[37], 72685 (6-phosphogluconate dehydrogenase gene) [37], 73903 (6-gluconolactonase gene) [46], and 57940 (alternative oxidase gene, aox1) [47] involved in tricarboxylic acid cycle, redox process or pentose phosphate pathway were selected as candidate regulators (Table 1). These genes were overexpressed in T. reesei.

\section{Plasmid construction}

We used the Gibson assembly [48], a method that utilizes the highly efficient in vitro homologous recombination machinery, to construct the plasmids in this study. To construct the plasmids overexpressing candidate genes, we first selected five strong promoters (cbh1 [49], pdc1 [50], gpd1[51], cDNA1 [52], xpp1 [53]) and terminators ( $x y r 1, p d c 1$, eno1, cDNA1, and xpp1) to construct five intermediate plasmids which contained a promoter and a corresponding terminator. These promoters and terminators were amplified from the genomic DNA of $T$. reesei, and the ampicillin resistance gene and E. coil replication origin were amplified from pCbh1pWT-DsRedTEL [54] (primers listed in Additional file 1: Table S1). Restriction enzymes SalI, SnaBI, PacI, and NdeI were added between the promoter and terminator for ease of inserting candidate genes. Then the four amplified DNA fragments were mixed with $2 \times$ ClonExpress Mix (ClonExpress Ultra One Step Cloning Kit, Vazyme, Nanjing, China), incubated at $50{ }^{\circ} \mathrm{C}$ for $15 \mathrm{~min}$, and transformed into the E. coli competent cell Fast-T1. The resultant intermediate plasmids pPcbh1-Tcbh1, pPpdc1-Tpdc1, pPgpd1-Teno1, pPcDNA1-TcDNA1, pPXpp1-TXpp1, and pPpki-Tcbh2 were digested with two of the four restriction enzymes, respectively. The experimentally verified or putatively positively acting regulator genes (xyr1, ace3, 26163, 66966, 122523, 80291, 64608, 123668, 27600, 74765, 80621, 53567, 75769, 72685, 73903, 52055, and 57940) were amplified from the genomic DNA of $T$. reese $i$ and inserted using Gibson assembly into the intermediate plasmids (Table 1).

To construct the plasmids for RNAi-mediated gene silencing of the repressors, we used the head-to-head dual promoters design [55]. Three intermediate plasmids (pPpdc1-Peno1, pPcDNA1-PXpp1, and pPtef1-Ppki) were constructed by Gibson assembly method, each of which contained two head-to-head dual promoters. All these promoters were amplified from the genomic DNA of T. reesei, while the ampicillin resistance gene and $E$. coil replication origin were amplified from pCbh1pWTDsRed-TEL (primers listed in Additional file 1: Table S1). Similarly, restriction enzymes SalI, SnaBI, PacI, and NdeI were added between the two promoters for ease of inserting the candidate genes. The constructed intermediate plasmids were restriction digested with two of the four enzymes. The verified or putatively negative regulators (ace1, cre1, sed1, der1, ych1, ymr1, och1-2, pep4, doa10, and yps1) were amplified from the genomic DNA of $T$. reese $i$ and individually inserted into one of the intermediate plasmids to obtain the RNAi plasmids (Table 1). The direct repeats of ampicillin resistance genes containing the pyr4 selection marker gene used for complementation of the uridine auxotrophy were amplified from the pAPA plasmid [28] with the primer pairs (listed in Additional file 1: Table S1).

\section{Transformation of $T$. reesei}

The plasmids encoding the selected genes were introduced into $T$. reesei by following a modified method of polyethylene glycol (PEG)-mediated protoplast transformation [56]. Briefly, T. reesei was grown in MM-glucose $(2 \%)$ at $28{ }^{\circ} \mathrm{C}$ for $20 \mathrm{~h}$. Mycelia were collected and incubated with $10 \mathrm{mg} / \mathrm{mL}$ of Lysing Enzymes (L1412, 
Sigma-Aldrich, St. Louis, MO) plus $1 \mathrm{mg} / \mathrm{mL}$ of cellulase (ONOZUKAR-10) at $30{ }^{\circ} \mathrm{C}$ until large amounts of protoplasts were released. Two $\mu \mathrm{g}$ each of selected plasmids and the APA fragment (half amount of total plasmids added) were used to co-transform the SUS4 protoplasts. The transformants were selected on MM-glucose agar plates for $5 \mathrm{~d}$. All transformant colonies were washed with sterile water and the mixed transformants were transferred to the potato dextrose agar (PDA) for resporulation. Spores were collected from the mixed transformants and used for FACS.

\section{FACS}

For flow cytometry-assisted cell sorting of spores, fresh spores were transferred into liquid MM-lactose/ sophorose ( $2 \%$ for lactose and $0.003 \%$ for sophorose, $\mathrm{w} / \mathrm{v}$ ) and shaken at $160 \mathrm{rpm}$ for $13 \mathrm{~h}$. Germinated spore suspensions were filtered through a 200-mesh sifter to remove long hyphae and chunks. High-speed sorting was performed in a FACS Aria sorter at a rate of 5,000 events per sec, 30 psi with an $85 \mathrm{~m}$ nozzle. Single cells with the brightest DsRed fluorescence signal (top 0.1\%) were sorted into individual wells of a 6-well plate and cultured at $28^{\circ} \mathrm{C}$ for sporulation.

For FACS analysis of protoplasts, fresh spores of the transformants were cultured in liquid MM-2\% glucose for $24 \mathrm{~h}$ and $1 / 10(\mathrm{v} / \mathrm{v})$ of the germinated spores were transferred to liquid MM-2\% Avicel and shaken at $160 \mathrm{rpm}$ for $72 \mathrm{~h}$. Then, the hyphae were collected for preparing protoplasts. Protoplasts were prepared using the method essentially the same as above described and passed through the FACS instrument. Protoplasts with the highest fluorescence signal were directly sorted into individual wells of a 96-well plate containing $1 \mathrm{M}$ sorbitol (to maintain the osmotic pressure) and MM with $2 \%$ glucose as the carbon source. The protoplasts were incubated for $96 \mathrm{~h}$ at $28^{\circ} \mathrm{C}$ with gentle shaking for regeneration of the cell wall and propagation. Then, $10 \mu \mathrm{l}$ of the cell suspension from each of the 96-well plate were transferred on PDA plate and cultured at $28^{\circ} \mathrm{C}$ for sporulation.

\section{Induction of cellulase production}

For induction of cellulase gene expression in T. reesei, $10^{7}$ fresh spores were inoculated into $50 \mathrm{ml}$ of liquid MM supplemented with $2 \%$ glucose and shaken at $28^{\circ} \mathrm{C}$ for $36 \mathrm{~h}$. The mycelia were filtered by passing the culture through a 200-mesh sifter and washed twice with MM to remove residual glucose. One gram of the mycelia was added to $100 \mathrm{ml}$ of MM-Avicel (2\%) for cellulase induction. From day 2 to 7 post-Avicel cellulose inoculation, $2 \mathrm{ml}$ of the culture were periodically taken out for assay of the cellulase activities and protein concentrations.
Assay of cellulase activity and protein concentration Since SUS4 is a strain with eg2-overexpression [27], the endoglucanase activity was used as an indicator of cellulase activity. For assay of endoglucanase, sodium carboxymethyl cellulose (CMC-Na, from Sigma-Aldrich) was used as the substrate. CMC-Na was dissolved in a Mcllvaine buffer (200 mM, pH 5.0). The reactions contained $900 \mu \mathrm{l}$ of $1.5 \%(\mathrm{w} / \mathrm{v}) \mathrm{CMC}-\mathrm{Na}$ and $100 \mu \mathrm{l}$ of appropriately diluted enzymes and they were incubated at $50{ }^{\circ} \mathrm{C}$ for $30 \mathrm{~min}$. Then $1.5 \mathrm{ml}$ of the DNS (3,5-dinitro-salicylic acid) reagent was added to the mixture and boiled for $5 \mathrm{~min}$ to terminate the reaction. One unit of endoglucanase activity was defined as the amount of enzyme that released $1 \mu \mathrm{mol}$ of reducing sugar per minute under the assay conditions. The extracellular protein concentration of the fermentation supernatants was determined using BCA-200 Protein Assay Kit (Pierce, Rockford, IL). The fermentation broth for wild-type and transformants were also analyzed by sodium dodecyl sulfate-polyacrylamide gel electrophoresis (SDS-PAGE). For assay of mycelial biomass, we used mycelial proteins as representatives of the fungal biomass to avoid the interference of insoluble cellulose Avicel. The mycelia of the strains were collected in different time periods from days 1 to 7 , and the method described by Jayaraman [57] was adopted to determine the mycelial proteins.

\section{Isolation of homokaryons and knockout of the pyr4 gene}

Selected T. reesei transformants were used for isolation of homokaryons by first sporulation on PDA plates. Then, $200 \mu \mathrm{l}$ of each of spore suspensions of the transformants at dilution rates of $10^{-1}, 10^{-2}, 10^{-3}, 10^{-4}, 10^{-5}$, and $10^{-6}$ were spread on the MM-glucose (2\%) agar plates containing $0.1 \%$ Triton X-100 and cultured for 4-5 d. For knocking out the pyr4 gene in the transformants, $200 \mu \mathrm{l}$ each of spore suspensions of the transformants at dilution rates of $10^{-1}, 10^{-2}, 10^{-3}, 10^{-4}$, and $10^{-5}$ were spread on MMglucose (2\%) agar plates containing $3 \mathrm{mg} / \mathrm{ml}$ of 5 -fluoroorotic acid (Biotopped, Beijing, China) and $10 \mathrm{mM}$ uridine (Sigma) and cultured for $7 \mathrm{~d}$. The transformants with pyr4 gene knocked out were tested for cellulase activity, and those with a similar cellulase-producing ability to that of the original strain were selected for further study.

\section{Determining insertion of selected genes in the transcription stage in the transformants}

To verify which gene(s) would be introduced into $T$. reesei and, therefore, be responsible for increased cellulase production, we randomly selected five transformants for genomic DNA extraction and determination of gene integration in the genome for the first round of 
transformation. The fungal genomic DNAs were isolated from the mycelia using a Fungal DNA kit (Omega Bio-Tek, Norcross, Georgia) and used as the template for PCR. Then, gene-specific primers (Additional file 1: Table S1) was designed and used to amplify the gene expressing cassettes from the transformants.

\section{Reverse transcription quantitative PCR}

The transcript level of major cellulase, hemicellulase, and selected genes was measured by reverse transcription quantitative PCR (RT-qPCR). The mycelia of T. reesei were collected and pulverized at the maximum speed for $60 \mathrm{~s}$ in liquid nitrogen using a Mini-Beadbeater (Biospec, Bartlesville, USA). Total RNA was extracted using the TRIzol reagent (Thermo Fisher Scientific, Waltham, MA). The RNA $(1 \mu \mathrm{g})$ was treated with DNase I and then reverse-transcribed to cDNA using the First Strand cDNA Maxima Synthesis kit (TOYOBO, Shanghai, China). RT-qPCR was performed in a QuantStudio 6 Flex Real-Time PCR System (Applied Biosystems, San Diego, CA) using a TransScript Green One-Step qRT-PCR SuperMix (TransGen, Beijing, China). The actin gene was used as a reference. The primers in RT-qPCR were listed in (Additional file 1: Table S1). The following PCR procedure was used: initial denaturation at $95^{\circ} \mathrm{C}$ for $10 \mathrm{~min}$ and then 40 cycles of $94^{\circ} \mathrm{C}$ for $10 \mathrm{~s}, 60^{\circ} \mathrm{C}$ for $20 \mathrm{~s}$, and $72{ }^{\circ} \mathrm{C}$ for $30 \mathrm{~s}$.

\section{Supplementary Information}

The online version contains supplementary material available at https://doi. org/10.1186/s13068-022-02122-0.

Additional file 1: Table S1. Primers used in this study. Figure S1. Effect of overexpressing xyr1 on cellulase production in SUS4. Figure S2. SDS-PAGE analysis of the fermentation broth of SUS4 and its mutant strains.

\section{Authors' contributions}

XS performed research, analyzed data, and wrote the paper. YL, YW, HZ and $\mathrm{HL}$ analyzed the data, TZ provided technical assistance, $\mathrm{HH}$ and BY designed research, XS conceived the idea and designed research, analyzed data, and wrote the paper. All authors read and approved the final manuscript.

\section{Funding}

This study was supported by the National Key Research and Development Program of China (2021YFC2100204), National Natural Science Foundation of China (32102583) and the China Agriculture Research System of MOF and MARA (CARS-41).

\section{Availability of data and materials \\ All data supporting the conclusions of this article are included within the manuscript and Additional file 1.}

\section{Declarations}

Ethics approval and consent to participate Not applicable.

\section{Consent for publication}

All authors provide their consent for publication of their manuscript in Biotechnology for Biofuels.

\section{Competing interests}

The authors declare that they have no competing interests.

\section{Author details}

${ }^{1}$ State Key Laboratory of Animal Nutrition, Institute of Animal Sciences, Chinese Academy of Agricultural Sciences, Beijing 100193, China. ${ }^{2}$ Institute of Microbiology, Chinese Academy of Sciences, Beijing 100101, China.

Received: 8 October 2021 Accepted: 19 February 2022

Published online: 05 March 2022

\section{References}

1. Xu XX, Li JY, Shi PJ, Ji WL, Liu B, Zhang YH, Yao B, Fan YL, Zhang W. The use of T-DNA insertional mutagenesis to improve cellulase production by the thermophilic fungus Humicola insolens Y1. Sci Rep-Uk. 2016;6:1-9.

2. Li FY, Liu Q, Li XL, Zhang CY, Li JG, Sun WL, Liu DD, Xiao DG, Tian CG. Construction of a new thermophilic fungus Myceliophthora thermophila platform for enzyme production using a versatile 2A peptide strategy combined with efficient CRISPR-Cas9 system. Biotechnol Lett. 2020:42:1181-91.

3. Schulein M. Enzymatic properties of cellulases from Humicola insolens. J Biotechnol. 1997:57:71-81.

4. Karnaouri AC, Topakas E, Christakopoulos P. Cloning, expression, and characterization of a thermostable GH7 endoglucanase from Myceliophthora thermophila capable of high-consistency enzymatic liquefaction. Appl Microbiol Biot. 2014;98:231-42.

5. Seidl V, Gamauf C, Druzhinina IS, Seiboth B, Hartl L, Kubicek CP. The Hypocrea jecorina (Trichoderma reesei) hypercellulolytic mutant RUT C30 lacks a $85 \mathrm{~kb}$ (29 gene-encoding) region of the wild-type genome. BMC Genomics. 2008;9:1-15.

6. Rassinger A, Gacek-Matthews A, Strauss J, Mach RL, Mach-Aigner AR. Truncation of the transcriptional repressor protein Cre1 in Trichoderma reesei Rut-C30 turns it into an activator. Fungal Biol Biotechnol. 2018;5:15.

7. Geysens S, Pakula T, Uusitalo J, Dewerte I, Penttila M, Contreras R. Cloning and characterization of the glucosidase II alpha subunit gene of Trichoderma reesei: a frameshift mutation results in the aberrant glycosylation profile of the hypercellulolytic strain Rut-C30. Appl Environ Microb. 2005;71:2910-24.

8. Wang S, Liu G, Wang J, Yu J, Huang B, Xing M. Enhancing cellulase production in Trichoderma reesei RUT C30 through combined manipulation of activating and repressing genes. J Ind Microbiol Biotechnol. 2013:40:633-41.

9. Liu R, Chen L, Jiang YP, Zhou ZH, Zou G. Efficient genome editing in filamentous fungus Trichoderma reesei using the CRISPR/Cas9 system. Cell Discov. 2015;1:1-11.

10. Miao Y, Xia Y, Kong Y, Zhu H, Mei H, Li P, Feng H, Xun W, Xu Z, Zhang $\mathrm{N}$, et al. Overcoming diverse homologous recombinations and single chimeric guide RNA competitive inhibition enhances Cas9-based cyclical multiple genes coediting in filamentous fungi. Environ Microbiol. 2021;23:2937-54.

11. Liu Q, Gao R, Li J, Lin L, Zhao J, Sun W, Tian C. Development of a genomeediting CRISPR/Cas9 system in thermophilic fungal Myceliophthora species and its application to hyper-cellulase production strain engineering. Biotechnol Biofuels. 2017;10:1.

12. Liu RM, Liang LY, Garst AD, Choudhury A, Nogue VSI, Beckham GT, Gill RT. Directed combinatorial mutagenesis of Escherichia coli for complex phenotype engineering. Metab Eng. 2018;47:10-20.

13. Lian JZ, HamediRad M, Hu SM, Zhao HM. Combinatorial metabolic engineering using an orthogonal tri-functional CRISPR system. Nat Commun. 2017;8:1-9.

14. Cherry JR, Fidantsef AL. Directed evolution of industrial enzymes: an update. Curr Opin Biotech. 2003;14:438-43.

15. Stricker AR, Grosstessner-Hain K, Wurleitner E, Mach RL. Xyr1 (xylanase regulator 1 ) regulates both the hydrolytic enzyme system and D-xylose metabolism in Hypocrea jecorina. Eukaryot Cell. 2006;5:2128-37. 
16. Aro N, Saloheimo A, Ilmen M, Penttila M. ACEll, a novel transcriptional activator involved in regulation of cellulase and xylanase genes of Trichoderma reesei. J Biol Chem. 2001;276:24309-14.

17. Zeilinger S, Ebner A, Marosits T, Mach R, Kubicek CP. The Hypocrea jecorina HAP 2/3/5 protein complex binds to the inverted CCAAT-box (ATTGG) within the cbh2 (cellobiohydrolase II-gene) activating element. Mol Genet Genomics. 2001;266:56-63.

18. Cao YL, Zheng FL, Wang L, Zhao GL, Chen GJ, Zhang WX, Liu WF. Rce 1, a novel transcriptional repressor, regulates cellulase gene expression by antagonizing the transactivator Xyr1 in Trichoderma reesei. Mol Microbiol. 2017;105:65-83.

19. Hakkinen M, Valkonen MJ, Westerholm-Parvinen A, Aro N, Arvas M, Vitikainen M, Penttila M, Saloheimo M, Pakula TM. Screening of candidate regulators for cellulase and hemicellulase production in Trichoderma reesei and identification of a factor essential for cellulase production. Biotechnol Biofuels. 2014;7:1-21.

20. Wang L, Lv XX, Cao YL, Zheng FL, Meng XF, Shen Y, Chen GJ, Liu WF, Zhang WX. A novel transcriptional regulator RXE1 modulates the essential transactivator XYR1 and cellulase gene expression in Trichoderma reesei. Appl Microbiol Biot. 2019;103:4511-23.

21. Wu Y, Sun X, Xue X, Luo H, Yao B, Xie X, Su X. Overexpressing key component genes of the secretion pathway for enhanced secretion of an Aspergillus niger glucose oxidase in Trichoderma reesei. Enzyme Microb Technol. 2017;106:83-7.

22. Moralejo FJ, Watson AJ, Jeenes DJ, Archer DB, Martin JF. A defined level of protein disulfide isomerase expression is required for optimal secretion of thaumatin by Aspegillus awamori. Mol Genet Genomics. 2001;266:246-53.

23. Hoshida H, Fujita T, Cha-aim K, Akada R. N-Glycosylation deficiency enhanced heterologous production of a Bacillus licheniformis thermostable alpha-amylase in Saccharomyces cerevisiae. Appl Microbiol Biotechnol. 2013;97:5473-82.

24. Pfeffer M, Maurer M, Stadlmann J, Grass J, Delic M, Altmann F, Mattanovich D. Intracellular interactome of secreted antibody Fab fragment in Pichia pastoris reveals its routes of secretion and degradation. Appl Microbiol Biotechnol. 2012;93:2503-12.

25. Delic M, Rebnegger C, Wanka F, Puxbaum V, Haberhauer-Troyer C, Hann S, Kollensperger G, Mattanovich D, Gasser B. Oxidative protein folding and unfolded protein response elicit differing redox regulation in endoplasmic reticulum and cytosol of yeast. Free Radical Bio Med. 2012;52:2000-12.

26. Nocon J, Steiger M, Mairinger T, Hohlweg J, Rumayer H, Hann S, Gasser B, Mattanovich D. Increasing pentose phosphate pathway flux enhances recombinant protein production in Pichia pastoris. Appl Microbiol Biot. 2016;100:5955-63.

27. Gao F, Hao Z, Sun X, Qin L, Zhao T, Liu W, Luo H, Yao B, Su X. A versatile system for fast screening and isolation of Trichoderma reesei cellulase hyperproducers based on DsRed and fluorescence-assisted cell sorting. Biotechnol Biofuels. 2018;11:261.

28. Sun X, Xue X, Li M, Gao F, Hao Z, Huang H, Luo H, Qin L, Yao B, Su X. Efficient coproduction of mannanase and cellulase by the transformation of a codon-optimized endomannanase gene from Aspergillus niger into Trichoderma reesei. J Agric Food Chem. 2017;65:11046-53.

29. Brody HM. RNAi-mediated gene silencing of highly expressed genes in the industrial fungi Trichoderma reesei and Aspergillus niger. Industrial Biotechnol. 2009;5:53-60.

30. Torres-Martinez S, Ruiz-Vazquez RM. The RNAi universe in fungi: a varied landscape of small RNAs and biological functions. Annu Rev Microbiol. 2017;71:371-91

31. Foreman PK, Brown D, Dankmeyer L, Dean R, Diener S, Dunn-Coleman NS, Goedegebuur F, Houfek TD, England GJ, Kelley AS, et al. Transcriptional regulation of biomass-degrading enzymes in the filamentous fungus Trichoderma reesei. J Biol Chem. 2003;278:31988-97.

32. Jain BP, Pandey S. WD40 repeat proteins: signalling scaffold with diverse functions. Protein J. 2018;37:391-406.

33. Ivanova C, Baath JA, Seiboth B, Kubicek CP. Systems analysis of lactose metabolism in Trichoderma reesei identifies a lactose permease that is essential for cellulase induction. PLoS ONE. 2013;8:e62631.

34. Parrish WR, Stefan CJ, Emr SD. Essential role for the myotubularin-related phosphatase Ymr1p and the synaptojanin-like phosphatases Sjl2p and $\mathrm{Sjl} 3 \mathrm{p}$ in regulation of phosphatidylinositol 3-phosphate in yeast. Mol Biol Cell. 2004;15:3567-79.
35. Schu PV, Takegawa K, Fry MJ, Stack JH, Waterfield MD, Emr SD. Phosphatidylinositol 3-kinase encoded by yeast VPS34 gene essential for protein sorting. Science. 1993;260:88-91.

36. Nie Y, Huang M, Lu J, Qian J, Lin W, Chu J, Zhuang Y, Zhang S. Impacts of high beta-galactosidase expression on central metabolism of recombinant Pichia pastoris GS115 using glucose as sole carbon source via (13)C metabolic flux analysis. J Biotechnol. 2014;187:124-34.

37. Sui YF, Schutze T, Ouyang LM, Lu H, Liu P, Xiao X, Qi J, Zhuang YP, Meyer V. Engineering cofactor metabolism for improved protein and glucoamylase production in Aspergillus niger. Microb Cell Fact. 2020;19:198.

38. Carvalho ND, Arentshorst M, Kooistra R, Stam H, Sagt CM, van den Hondel CA, Ram AF. Effects of a defective ERAD pathway on growth and heterologous protein production in Aspergillus niger. Appl Microbiol Biotechnol. 2011;89:357-73.

39. Driouch $\mathrm{H}$, Melzer $\mathrm{G}$, Wittmann C. Integration of in vivo and in silico metabolic fluxes for improvement of recombinant protein production. Metab Eng. 2012;14:47-58.

40. Pedersen H, Christensen B, Hjort C, Nielsen J. Construction and characterization of an oxalic acid nonproducing strain of Aspergillus niger. Appl Environ Microbiol. 2000;2:34-41.

41. Pakula TM, Laxell M, Huuskonen A, Uusitalo J, Saloheimo M, Penttila $M$. The effects of drugs inhibiting protein secretion in the filamentous fungus Trichoderma reesei. Evidence for down-regulation of genes that encode secreted proteins in the stressed cells. J Biol Chem. 2003;278:45011-20.

42. Gansemer ER, McCommis KS, Martino M, King-McAlpin AQ, Potthoff MJ, Finck BN, Taylor EB, Rutkowski DT.NADPH and glutathione redox link TCA cycle activity to Endoplasmic Reticulum homeostasis. iScience. 2020;23:101116.

43. Zhang GF, Jensen MV, Gray SM, El K, Wang Y, Lu D, Becker TC, Campbell JE, Newgard CB. Reductive TCA cycle metabolism fuels glutamine- and glucose-stimulated insulin secretion. Cell Metab. 2021;33:804-817 e805.

44. Du J, Yuan Y, Si T, Lian J, Zhao H. Customized optimization of metabolic pathways by combinatorial transcriptional engineering. Nucleic Acids Res. 2012;40:e142.

45. Antonieto AC, dos Santos CL, Silva-Rocha R, Persinoti GF, Silva RN. Defining the genome-wide role of CRE1 during carbon catabolite repression in Trichoderma reesei using RNA-Seq analysis. Fungal Genet Biol. 2014;73:93-103.

46. Nocon J, Steiger M, Mairinger T, Hohlweg J, Russmayer H, Hann S, Gasser B, Mattanovich D. Increasing pentose phosphate pathway flux enhances recombinant protein production in Pichia pastoris. Appl Microbiol Biotechnol. 2016;100:5955-63.

47. Vemuri GN, Eiteman MA, McEwen JE, Olsson L, Nielsen J. Increasing $\mathrm{NADH}$ oxidation reduces overflow metabolism in Saccharomyces cerevisiae. Proc Natl Acad Sci U S A. 2007;104:2402-7.

48. Gibson DG, Young L, Chuang RY, Venter JC, Hutchison CA 3rd, Smith HO. Enzymatic assembly of DNA molecules up to several hundred kilobases. Nat Methods. 2009;6:343-5.

49. Xue X, Wu Y, Qin X, Ma R, Luo H, Su X, Yao B. Revisiting overexpression of a heterologous beta-glucosidase in Trichoderma reesei: fusion expression of the Neosartorya fischeri Bgl3A to cbh 1 enhances the overall as well as individual cellulase activities. Microb Cell Fact. 2016;15:122.

50. Li J, Wang J, Wang S, Xing M, Yu S, Liu G. Achieving efficient protein expression in Trichoderma reesei by using strong constitutive promoters. Microb Cell Fact. 2012;11:84.

51. Schmoll M, Schuster A, Silva Rdo N, Kubicek CP. The G-alpha protein GNA3 of Hypocrea jecorina (Anamorph Trichoderma reesei) regulates cellulase gene expression in the presence of light. Eukaryot Cell. 2009;8:410-20.

52. Uzbas F, Sezerman U, Hartl L, Kubicek CP, Seiboth B. A homologous production system for Trichoderma reesei secreted proteins in a cellulase-free background. Appl Microbiol Biotechnol. 2012;93:1601-8.

53. Chen $X$, Luo $Y, Y u$ H, Sun $Y$, Wu H, Song S, Hu S, Dong Z. Transcriptional profiling of biomass degradation-related genes during Trichoderma reesei growth on different carbon sources. J Biotechnol. 2014;173:59-64.

54. Sun $X$, Zhang $X$, Huang H, Wang Y, Tu T, Bai Y, Zhang J, Luo H, Yao B, Su X. Engineering the cbhl promoter of Trichoderma reesei for enhanced protein production by replacing the binding sites of a transcription repressor ACE1 to those of the activators. J Agric Food Chem. 2020;68:1337-46. 
55. Su X, Qin L, Dong Z. RNAi-mediated gene silencing in Trichoderma: principles and applications. Elsevier BV; 2014.

56. Penttila M, Nevalainen H, Ratto M, Salminen E, Knowles J. A versatile transformation system for the cellulolytic filamentous fungus Trichoderma reesei. Gene. 1987;61:155-64.

57. Jayaraman J, Cotman C, Mahler HR, Sharp CW. Biochemical correlates of respiratory deficiency VII. Glucose repression. Arch Biochem Biophys. 1966;116:224-51.

58. Saloheimo A, Aro N, IImen M, Penttila M. Isolation of the acel gene encoding a Cys(2)-His(2) transcription factor involved in regulation of activity of the cellulase promoter cbh 1 of Trichoderma reesei. J Biol Chem. 2000;275:5817-25.

59. Rajakumar S, Vijayakumar R, Abhishek A, Selvam GS, Nachiappan V. Loss of ERAD bridging factor UBX2 modulates lipid metabolism and leads to ER stress-associated apoptosis during cadmium toxicity in Saccharomyces cerevisiae. Curr Genet. 2020;66:1003-17.

60. Hossain AH, van Gerven R, Overkamp KM, Lubeck PS, Taspinar H, Turker M, Punt PJ. Metabolic engineering with ATP-citrate lyase and nitrogen source supplementation improves itaconic acid production in Aspergillus niger. Biotechnol Biofuels. 2019;12:233.

61. Kobayashi K, Hattori T, Hayashi R, Kirimura K. Overexpression of the $\mathrm{NADP}+$-specific isocitrate dehydrogenase gene (icdA) in citric acidproducing Aspergillus niger WU-2223L. Biosci Biotechnol Biochem. 2014;78:1246-53.

62. Liochev SI, Fridovich I. Superoxide generated by glutathione reductase initiates a vanadate-dependent free radical chain oxidation of $\mathrm{NADH}$. Arch Biochem Biophys. 1992;294:403-6.

\section{Publisher's Note}

Springer Nature remains neutral with regard to jurisdictional claims in published maps and institutional affiliations.
Ready to submit your research? Choose BMC and benefit from:

- fast, convenient online submission

- thorough peer review by experienced researchers in your field

- rapid publication on acceptance

- support for research data, including large and complex data types

- gold Open Access which fosters wider collaboration and increased citations

- maximum visibility for your research: over $100 \mathrm{M}$ website views per year

At BMC, research is always in progress.

Learn more biomedcentral.com/submissions 